\title{
INDUKSI TUNAS, MULTIPLIKASI DAN PERAKARAN Gyrinops versteegii (Gilg.) Domke SECARA IN VITRO
}

The induction of shoots, multiplication, and rooting of

Gyrinops versteegii (Gilg.) Domke by in vitro

\author{
Aziz Akbar $\mathbf{M}^{1}$, Eny Faridah ${ }^{2}$, Sapto Indrioko ${ }^{2}$, dan Toni Herawan ${ }^{3}$ \\ ${ }^{1}$ Program Magister Ilmu Kehutanan, Fakultas Kehutanan, Universitas Gadjah Mada \\ Jl. Agro No.1, Bulaksumur, Sleman, Yogyakarta, Indonesia \\ email: asyaf@gmail.com \\ ${ }^{2}$ Fakultas Kehutanan, Universitas Gadjah Mada \\ Jl. Agro No.1, Bulaksumur, Sleman, Yogyakarta, Indonesia \\ ${ }^{3}$ Balai Besar Penelitian dan Pengembangan Bioteknologi dan Pemuliaan Tanaman Hutan \\ Jl. Palagan Tentara Pelajar Km. 15, Purwobinangun, Pakem, Sleman, Yogyakarta, Indonesia
}

Tanggal diterima: 18 Desember 2015, Tanggal direvisi: 14 Februari 2016, Disetujui terbit: 20 Maret 2017

\begin{abstract}
Gyrinops versteegii (Gilg.) Domke is including one of superior agarwood-producing plants and naturally growing in Eastern Indonesia as Nusa Tenggara and Papua. Indonesia has been trading agarwood products both domestically and overseas which one of them is agarwood produced by G.versteegii. This study purpose was to develop an in vitro culture method for mass propagation of $G$. versteegii. Shoot induction conducted on MS medium supplemented with Benzyl Amino Purine (BAP) 0.7; 1.0; 1.5; and $2.0 \mathrm{mg} / \mathrm{l}$. The shoots multiplication conducted on MS medium supplemented with the best concentration of BAP from shoot induction phase. The rooting of shoots conducted on half strength MS medium supplemented with interaction of Napthalene Acetic Acid (NAA) $0.01 \mathrm{mg} / \mathrm{l}$ with concentration of Indole-3-Butyric Acid (IBA) 1.0; 2.0; 3.0; and $4.0 \mathrm{mg} / \mathrm{l}$. Epicotyl explant with a given concentration level of BAP $0.7 \mathrm{mg} / \mathrm{l}$ produce the highest rates number of shoots and shoot length compared to other explant respectively 4.8 shoots and $0.41 \mathrm{~cm}$ within 6 weeks. The best explant developments in the best medium able to promote the growth of the length and number of shoots are 0.28 shoots and $0.3 \mathrm{~cm}$ within 4 weeks. Explants easiest, quickest and most high sprouting ability as a factor of success in terms of multiplication is epicotyl. The combination treatment of material explant with concentration of BAP only affect to growth of shoots length. The combination treatment of NAA with concentration of IBA has no effect against root formation and growth rootlength.
\end{abstract}

\section{Keywords: induction of shoot, multiplication, rooting, in vitro, Gyrinops versteegii}

\begin{abstract}
ABSTRAK
Gyrinops versteegii (Gilg.) Domke termasuk salah satu tumbuhan penghasil gaharu superior dan hanya terdapat di Indonesia bagian timur yaitu Nusa Tenggara dan Papua. Indonesia telah memperdagangkan produk gaharu dimana salah satunya dihasilkan oleh $G$. versteegii baik dalam negeri ataupun luar negeri. Tujuan penelitian ini adalah pengembangan metode budidaya in vitro untuk perbanyakan massal dari jenis ini. Penelitian ini dilaksanakan secara tiga tahap yaitu induksi tunas, multiplikasi, dan perakaran. Tahap induksi tunas dilakukan pada media MS yang diberi tambahan hormon BAP (Benzyl Amino Purine) dengan konsentrasi 0,7; 1,0; 1,5; dan 2,0 mg/l. Tahap multiplikasi dilakukan pada media MS yang diberi hormon BAP dengan konsentrasi terbaik dari tahap induksi tunas. Tahap perakaran dilakukan pada media $1 / 2$ MS yang diberi tambahan hormon NAA (Naphthalene Acetic Acid) 0,01 mg/l dengan hormon IBA (Indole-3-Butyric Acid) konsentrasi 1,0; 2,0; 3,0; dan 4,0 mg/l. Materi eksplan epikotil dengan diberi tingkat konsentrasi hormon BAP $0,7 \mathrm{mg} / \mathrm{l}$ menghasilkan jumlah tunas dan panjang tunas tertinggi dibandingkan eksplan lainnya yaitu berturut-turut 4,8 tunas dan $0,41 \mathrm{~cm}$ dalam waktu 6 minggu. Perkembangan eksplan terbaik dalam media terbaik dapat meningkatkan jumlah tunas dan pertumbuhan panjang tunas berturut-turut yaitu 0,3 tunas dan $0,28 \mathrm{~cm}$ dalam waktu 4 minggu. Eksplan yang paling mudah, cepat dan paling tinggi kemampuan bertunasnya sebagai faktor keberhasilan dalam hal multiplikasi adalah epikotil. Kombinasi perlakuan antara materi eksplan dengan konsentrasi BAP hanya mempengaruhi pertumbuhan panjang tunas. Kombinasi perlakuan hormon NAA dengan konsentrasi hormon IBA tidak memiliki pengaruh yang nyata terhadap pembentukan akar dan pertumbuhan panjang akar.
\end{abstract}

Kata kunci: induksi tunas, multiplikasi, perakaran, in vitro, Gyrinops versteegi 


\section{PENDAHULUAN}

Indonesia merupakan negara produsen gaharu terbesar di dunia yang pada akhir tahun 1990 mampu menghasilkan gaharu lebih dari 600 ton/tahun, tetapi sejak tahun 2000 kuota produksinya menurun hingga $10 \%-15 \%$. Berkembangnya nilai pemanfaatan produk gaharu dibeberapa negara industri juga meningkatkan tekanan terhadap populasi tanaman penghasil gaharu di alam untuk diperoleh produk gaharunya (Sumarna, 2012). Terlebih lagi, kualitas produk gaharu (kandungan resin) yang dihasilkan berasal dari hutan alam lebih baik dibandingkan gaharu hasil inokulan buatan (Jensen, 2003; Mucharromah, 2009; Sidiyasa \& Mira, 2009). Hal tersebut yang menyebabkan tanaman ini pada populasi alaminya menjadi langka, sehingga di tahun 2004 jenis ini termasuk pada Red List IUCN jenis yang terancam punah dan APPENDIX II CITES (CITE, 2004). Jenis G. Versteegii termasuk salah satu tumbuhan penghasil gaharu dengan kualitas superior, terlebih lagi G. versteegii hanya terdapat di Indonesia bagian timur yaitu Nusa Tenggara dan Papua (Mulyaningsih \& Yamada, 2008).

Penelitian perbanyakan secara makro dengan stek pucuk Aquilaria malaccensis (Muswita, 2011) yang diberi auksin alami dapat menghasilkan 2 tunas (konsentrasi 0,5\%) dan 5,4 akar (konsentrasi 1\%). Namun, penelitian perbanyakan secara mikro dengan eksplan tunas pucuk Aquilaria malaccensis secara in vitro oleh Sabdin, Muid, dan Sani (2011) diberi zat pengatur tumbuh dapat menghasilkan 18 tunas (konsentrasi BAP 0,5 mg/l) dan 11 akar (persentase berakar 70\%) (konsentrasi IBA 1 $\mathrm{mg} / \mathrm{l})$. Perbandingan kedua metode tersebut dapat diketahui bahwa metode perbanyakan secara mikro menghasilkan tunas dan akar lebih baik dibandingkan perbanyakan secara makro. Oleh karena itu, sangat dimungkinkan penggunaan metode propagasi mikro terhadap jenis G. versteegii akan mendapatkan hasil yang baik.
Keberhasilan dari teknik kultur jaringan juga dipengaruhi oleh beberapa faktor seperti pemilihan eksplan yang tepat sebagai bahan dasar terkait juvenilitas dari jaringan eksplan tersebut; komposisi medium tumbuh dan zat pengatur tumbuh yang sesuai, karena tiap jenis tanaman yang berbeda atau bahkan bagian organ/sel/jaringan dari tanaman yang sama dapat memberikan respon yang berbeda (Salisbury, Ross, \& Lukman, 1995); keadaan lingkungan yang aseptik serta pengaturan udara yang baik, dan cara sterilisasinya (Hendaryono \& Wijayani, 2012; Herawan \& Hendrati, 1996; Zulkarnain, 2014).

Hormon yang biasa digunakan dalam penelitian kultur jaringan adalah kelompok sitokinin dan auksin. Pembentukan tunas lebih dipengaruhi oleh hormon sitokinin. Hormon BAP termasuk hormon sintetik dan memiliki sifat lebih stabil dan kuat dibandingkan jenis hormon sitokinin lainnya seperti kinetin dan zeatin. Secara umum, BAP memiliki pengaruh utama dalam perkembangan eksplan yaitu dalam pembentukan tunas, multiplikasi tunas, dan mamacu pembelahan sel dalam metabolisme tanaman untuk membentuk bagian/organ yang diperlukan (Ashraf, Aziz, Kemat, \& Ismail, 2014). Harahap, Poerwanto, Suharsono, Suriani, dan Rahayu, (2014) menyatakan bahwa konsentrasi BAP yang sesuai akan bekerja dengan optimal pada tanaman tertentu dalam hal induksi tunas. Pertumbuhan perakaran pada eksplan dapat dikontrol dengan pemberian zat pengatur tumbuh golongan auksin. Kelompok auksin yang biasa digunakan dalam kultur jaringan adalah NAA (Naphthalene Acetic Acid) dan IBA (Indole-3-Butyric Acid). Hartmann, Kester, Davies, dan Geneve, (1990) mengungkapkan bahwa pemberian kombinasi IBA dan NAA lebih efektif pengaruhnya utamanya untuk meningkatkan persentase berakar dan jumlah akar pada eksplan dibandingkan dengan hormon tunggal.

Penelitian induksi tunas yang dicobakan terhadap beberapa materi eksplan G. versteegii masih belum banyak dilakukan. Begitu pula 
dengan penelitian induksi akar pada eksplan G. versteegii yang belum pernah dilakukan. Oleh karena itu, perlu adanya penelitian mengenai penentuan penggunaan metode propagasi mikro yang sesuai seperti konsentrasi atau kombinasi antar zat pengatur tumbuh agar dapat mendukung pertumbuhan serta perkembangan baik tunas dan akar pada eksplan G. versteegii dan pemilihan bagian eksplan $G$. Versteegii yang sesuai untuk mendukung kemampuan eksplan dalam memproduksi tunas dan akar. Hal tersebut diupayakan agar dapat mendukung keberhasilan propagasi mikro jenis $G$. versteegii.

\section{METODE PENELITIAN}

Penelitian ini dilaksanakan di Balai Besar Penelitian dan Pengembangan Bioteknologi dan Pemuliaan Tanaman Hutan (BBPPBPTH), berlokasi di daerah Purwobinangun, Pakem, Sleman, Yogyakarta. Penelitian dilaksanakan pada bulan Februari hingga bulan Agustus 2015. Bahan tanaman adalah biji $G$. versteegii yang berasal dari daerah Mataram, Nusa Tenggara Barat. Biji G. versteegii kemudian disterilisasi dua kali yaitu pertama, di luar laminar air flow cabinet menggunakan campuran larutan surfaktan anionik 16,38\% dengan natrium salisilat $0,15 \%$ dan benomyl $1 \mathrm{gr} / 500 \mathrm{ml}$. Kedua, sterilisasi di dalam laminar air flow cabinet menggunakan larutan alkohol $70 \%$ selama 1 menit dan sodium hypochlorite $2 \%$ selama 15 menit. Biji yang telah steril kemudian dikecambahkan secara in vitro pada media dasar White hingga muncul 2 daun (6 minggu). Selanjutnya, kecambah di potong bagian epikotil, kotiledon, hipokotil, dan radikula untuk digunakan sebagai eksplan.

Penelitian ini secara umum menggunakan metode rancangan acak lengkap (RAL). Setelah dilakukan kultur, botol kultur kemudian diinkubasi di rak kultur yang dilengkapi lampu fluorocent pada ruang kultur dengan kondisi lingkungan yang sama yaitu kondisi lingkungan ruang kultur dengan kelembaban 52\% dan photoperiodic 16 jam terang dengan $20-40 \mu$
E/m2 (8 jam gelap pukul 17.00 - 24.00), dan suhu $22^{\circ} \mathrm{C}-26^{\circ} \mathrm{C}$. Penelitian ini dilaksanakan tiga tahap, pertama yaitu tahap induksi tunas. Perlakuan yang digunakan berupa bagian eksplan dan konsentrasi hormon BAP. Eksplan yang digunakan adalah bagian dari kecambah G. versteegii, antara lain bagian epikotil, kotiledon, hipokotil, dan radikula. Eksplan tersebut kemudian dikulturkan secara in vitro ke dalam botol kultur pada laminar air flow cabinet. Botol kultur menggunakan media dasar MS dan ditambah hormon BAP dengan konsentrasi 0,7; 1,$0 ; 1,5 ;$ dan $2,0 \mathrm{mg} / \mathrm{l}$. Tahap awal ini menggunakan 10 kali ulangan, sehingga totalnya adalah 160 unit penelitian. Pengamatan induksi tunas dilakukan selama 6 minggu.

Tahap kedua adalah multiplikasi, eksplan yang digunakan yaitu eksplan terbaik hasil tahap induksi tunas. Eksplan kemudian disubkultur secara in vitro selama 4 minggu pada media dasar MS yang diberi konsentrasi hormon terbaik dari tahap sebelumnya. Pada tahap ini tidak terdapat perlakuan, hanya mengetahui perkembangan lanjutan dari tahap pertama. Total unit penelitian yang digunakan adalah eksplan yang masih hidup selama tahap pertama (tahap induksi tunas).

Tahap ketiga adalah induksi perakaran. Eksplan yang digunakan adalah tunas pada eksplan dari hasil tahap multiplikasi. Tunas pada eksplan terlebih dahulu diseleksi dengan kriteria minimal panjang tunas $0,5 \mathrm{~cm}$ dengan batang tunas yang gemuk dan kuat. Eksplan kemudian disubkultur secara in vitro selama 4 minggu pada media dasar $1 / 2$ MS dan diberi kombinasi perlakuan antara hormon NAA $0,01 \mathrm{mg} / 1$ dengan konsentrasi IBA 1,0; 2,0; 3,0; dan 4,0 mg/l. Pada tahap ini terdapat perlakuan berupa variasi pemberian kombinasi konsentrasi hormon NAA dan IBA. Tahap ketiga (induksi perakaran) ini menggunakan 9 kali ulangan, sehingga totalnya adalah 36 unit penelitian. 


\section{HASIL DAN PEMBAHASAN}

\section{A. Tahap induksi tunas}

\section{Persentase eksplan hidup, terkontaminasi, dan mati}

Persentase hidup eksplan tertinggi terdapat pada perlakuan eksplan epikotil dengan konsentrasi BAP $0,7 \mathrm{mg} / \mathrm{l}\left(\mathrm{M}_{1} \mathrm{E}_{1}\right)$ yaitu $100 \%$. Beberapa eksplan mengalami kematian pada minggu ke-5. Persen kematian eksplan adalah beragam pada tiap perlakuan. Beberapa eksplan warna tunasnya berubah menjadi coklat (browning) sebelum mengalami kematian. Browning pada eksplan dimungkinkan karena eksplan tersebut terlambat untuk dipindahkan pada media tumbuh yang baru. Hendaryono dan Wijayani, (2012) menjelaskan kondisi browning dikarenakan kehabisan nutrisi dan pertumbuhannya berhenti sehingga pada interval waktu tertentu eksplan harus dipindahkan ke dalam media tumbuh yang baru. Konsentrasi BAP $1,5 \mathrm{mg} / \mathrm{l}$ pada tiap materi eksplan mengalami kontaminasi terbesar. Kontaminasi yang terjadi tersebut dimungkinkan karena oleh faktor teknis dan faktor eksternal. Faktor teknis yaitu pengalaman dan keterampilan dalam mengkulturkan eksplan ketika di laminar air flow cabinet. Faktor eksternal yaitu lama penyimpanan dan kondisi penyimpanan botol kultur tersebut.

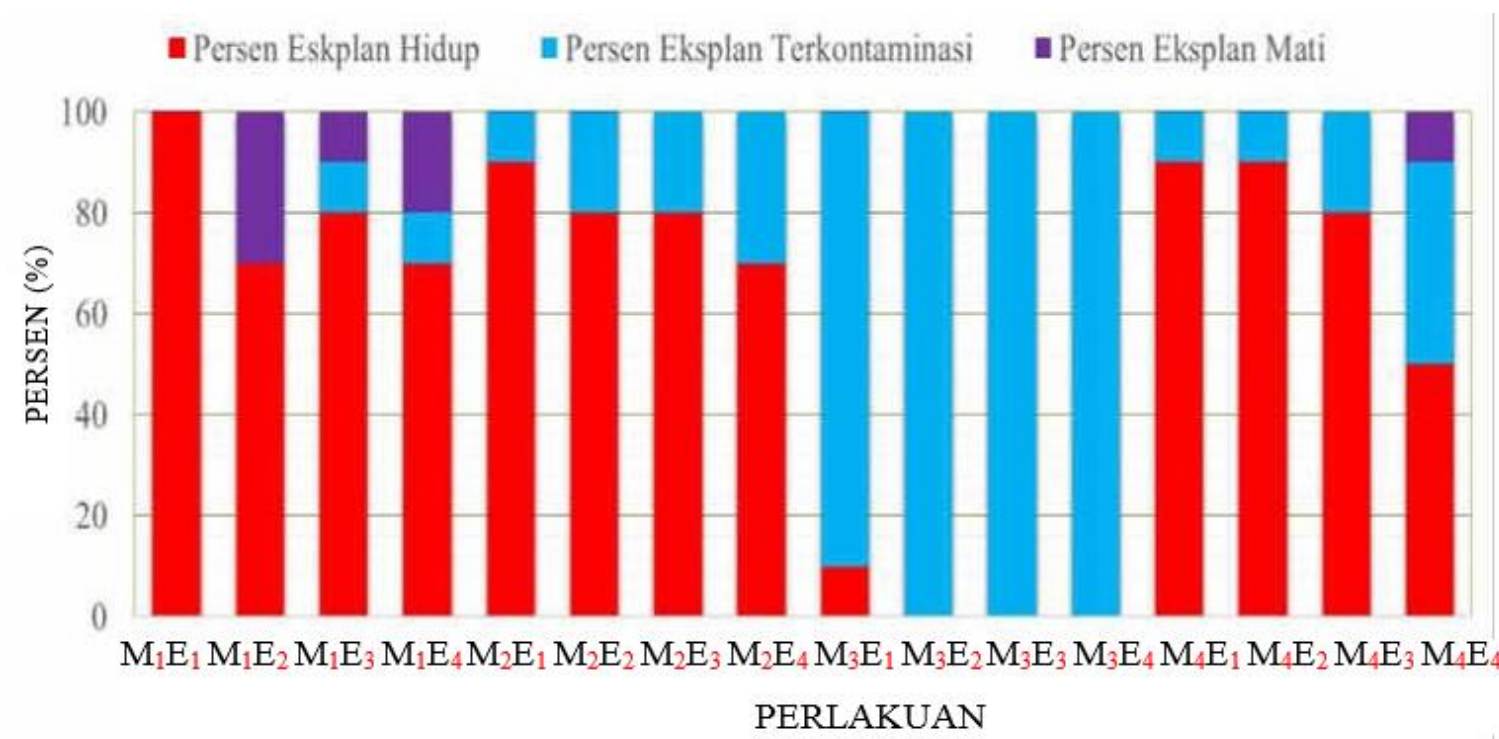

Keterangan : Konsentrasi BAP 0,7 mg/l ( $\left.\mathbf{M}_{1}\right)$, Konsentrasi BAP 1,0 mg/l ( $\left.\mathbf{M}_{2}\right)$, Konsentrasi BAP 1,5 mg/l ( $\left.\mathbf{M}_{3}\right)$, Konsentrasi BAP 2,0 mg/l $\left(\mathrm{M}_{4}\right)$, Epikotil $\left(\mathrm{E}_{1}\right)$, Kotiledon $\left(\mathrm{E}_{2}\right)$, Hipokotil $\left(\mathrm{E}_{3}\right)$, dan Radikula $\left(\mathrm{E}_{4}\right)$

Gambar 1. Persentase eksplan yang hidup, terkontaminasi, dan mengalami kematian hingga pengamatan ke-18 (selama 6 minggu)

\section{Kondisi tunas}

Tunas adalah proliferasi massa jaringan yang belum terdiferensiasi. Tunas yang muncul pada eksplan merupakan fase respon perkembangan eksplan akibat perlukaan saat melakukan kultur dan pengaruh perlakuan yang diberikan untuk beregenerasi menjadi tanaman lengkap (Hendaryono \& Wijayani, 2012; Power \& Ochat, 1992). Pembentukan tunas merupakan salah satu indikator keberhasilan dalam kultur jaringan. Eksplan yang terbentuk tunas hanya epikotil $\left(\mathrm{E}_{1}\right)$ dan kotiledon $\left(\mathrm{E}_{2}\right)$, sedangkan hipokotil $\left(\mathrm{E}_{3}\right)$ dan radikula $\left(\mathrm{E}_{4}\right)$ hanya sampai membentuk kalus saja. Kombinasi perlakuan konsentrasi BAP $0,7 \mathrm{mg} / \mathrm{l}$ dengan eksplan epikotil $\left(\mathrm{M}_{1} \mathrm{E}_{1}\right)$ memiliki rerata waktu muncul tunas tercepat dibandingkan yang lain yaitu sekitar 7 hari setelah kultur, sementara lainnya sekitar 9-11 hari. Kecepatan waktu muncul tunas pada eksplan kotiledon lebih lama dibanding epikotil yaitu sekitar 33 hari setelah kultur. 
Kondisi tunas tiap eksplan beragam seperti tunas yang berukuran panjang dengan nodus panjang dan tunas berukuran pendek dengan nodus yang rapat. Perbedaan kondisi tunas kemungkinan karena serapan hara pada tiap eksplan yang berbeda untuk regenerasi seperti pertumbuhan dan perkembangan tunas. Kemungkinan yang lain adalah adaptasi pertumbuhan dan perkembangan eksplan dalam lingkungan yang kecil seperti pada botol kultur. Kenampakan visual tunas pada eksplan dapat dilihat pada Gambar 2.

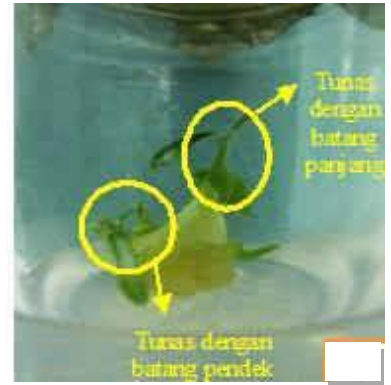

Gambar 2. Kenampakan Visual Tunas pada Eksplan

\section{Jumlah tunas dan panjang tunas}

Pembentukan tunas didominasi oleh eksplan epikotil $\left(\mathrm{E}_{1}\right)$ pada tiap konsentrasi BAP, selain itu pertumbuhan tunas pada tiap eksplan adalah beragam. Dinamika pertumbuhan rerata jumlah tunas berdasarkan perlakuan media (A) dan eksplan (B) tersaji pada Gambar 3.

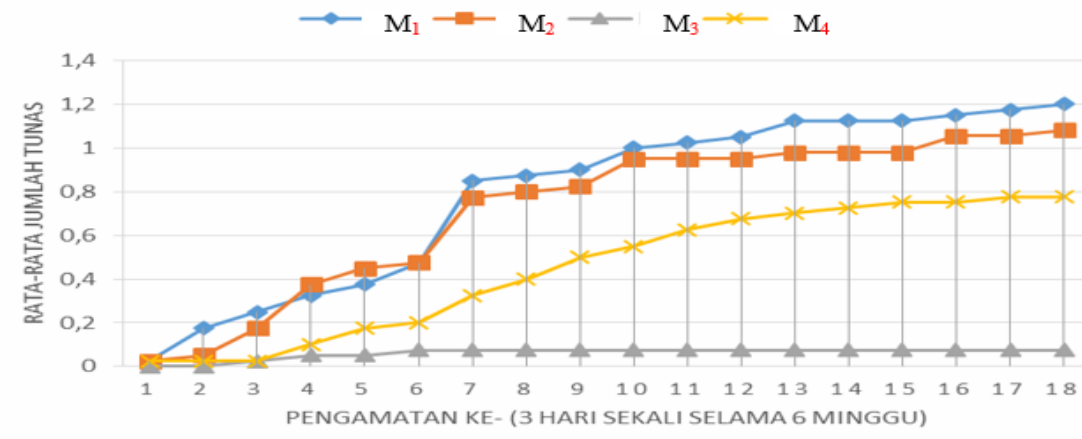

(A)

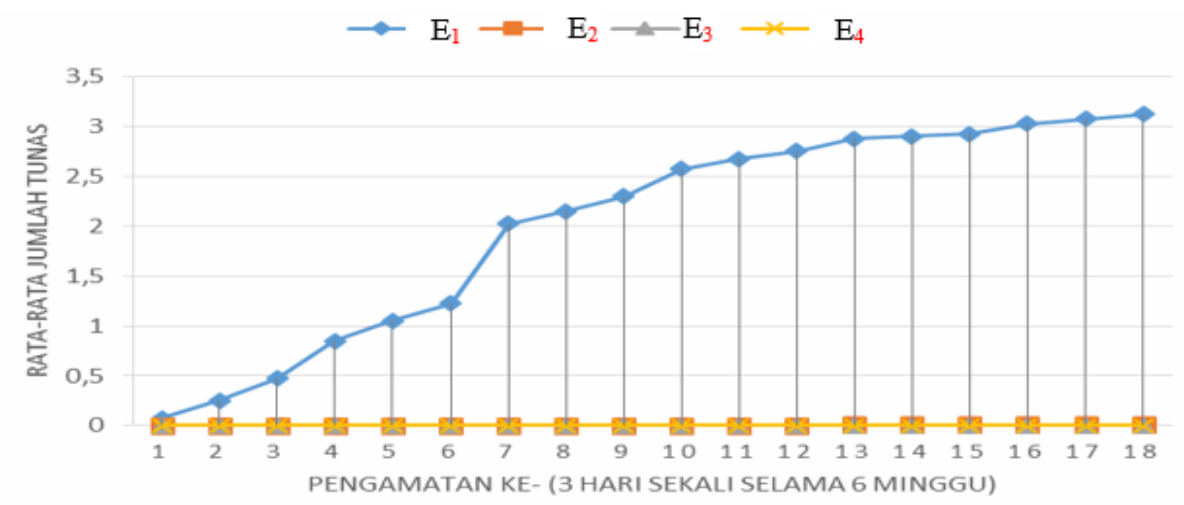

(B)

Keterangan: Konsentrasi BAP 0,7 mg/l ( $\left.\mathrm{M}_{1}\right)$, Konsentrasi BAP 1,0 mg/l (M $\left.\mathrm{M}_{2}\right)$, Konsentrasi BAP 1,5 mg/l (M $\left.\mathrm{M}_{3}\right)$, Konsentrasi BAP 2,0 mg/l $\left(\mathrm{M}_{4}\right)$, Epikotil $\left(\mathrm{E}_{1}\right)$, Kotiledon $\left(\mathrm{E}_{2}\right)$, Hipokotil $\left(\mathrm{E}_{3}\right)$, dan Radikula $\left(\mathrm{E}_{4}\right)$

Gambar 3. Dinamika Pertumbuhan Rerata Jumlah Tunas selama Pengamatan Berdasarkan A) Tingkat Konsentrasi Hormon BAP dan B) Materi Eksplan 
Gambar 3 menjelaskan bahwa rerata jumlah tunas tertinggi pada perlakuan eksplan epikotil dengan konsentrasi BAP $0,7 \mathrm{mg} / \mathrm{l}$ $\left(\mathrm{M}_{1} \mathrm{E}_{1}\right)$ adalah 4,8 tunas dalam waktu 6 minggu. Rerata jumlah tunas terendah pada perlakuan eksplan kotiledon dengan konsentrasi BAP 2 $\mathrm{mg} / \mathrm{l}\left(\mathrm{M}_{4} \mathrm{E}_{2}\right)$ yaitu 0,1 tunas. Tetapi, bila dilihat secara sendiri-sendiri baik materi eksplan maupun media hormon BAP, rerata jumlah tunas yang dihasilkan oleh materi eksplan epikotil $\left(\mathrm{E}_{1}\right)$ memiliki rata-rata jumlah tunas tertinggi yaitu 3,125 tunas (Gambar 3B). Sedangkan, rerata jumlah tunas tertinggi yang dihasilkan oleh media hormon BAP adalah hormon BAP 0,7 $\mathrm{mg} / \mathrm{l}\left(\mathrm{M}_{1}\right)$ yaitu 1,2 tunas (Gambar 3A). Bila dilihat dari jumlah tunas yang muncul berdasarkan materi eksplannya (Gambar3B), eksplan epikotil $\left(E_{2}\right)$ memiliki jumlah tunas yang muncul tertinggi kemudian kotiledon. Jumlah tunas yang muncul pada eksplan kotiledon rataratanya adalah 0,1 tunas, sehingga pada grafik (Gambar 3B) garis untuk eksplan kotiledon sama dengan eksplan hipokotil $\left(\mathrm{E}_{3}\right)$ dan radikula $\left(\mathrm{E}_{4}\right)$. Sedangkan eksplan hipokotil dan radikula tidak ada tunas yang muncul. Ada dan tidaknya tunas yang muncul pada materi eksplan dapat dilihat pada Gambar 4.

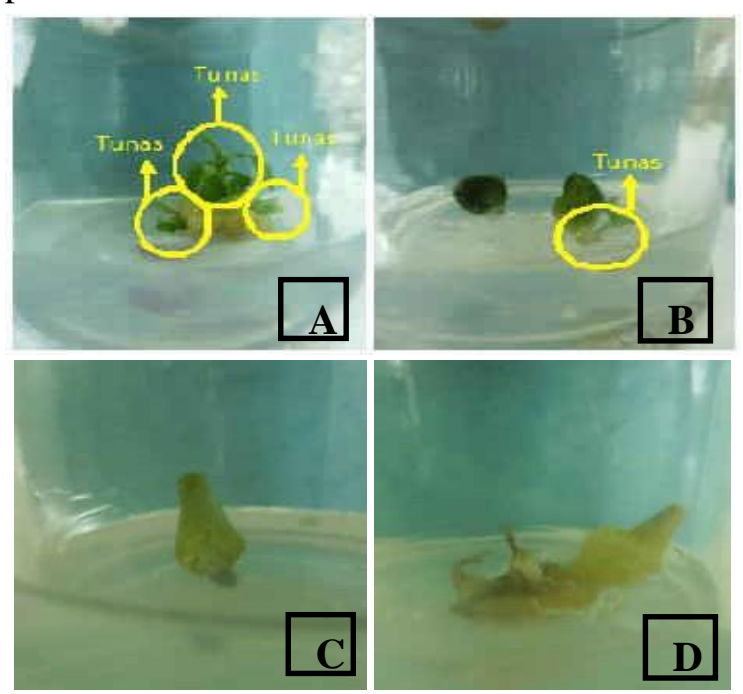

Gambar 4. Eksplan yang telah Membentuk Tunas A) Epikotil ( $\left.E_{1}\right)$, B) Kotiledon $\left.\left(E_{2}\right), C\right)$ Hipokotil ( $\left.\mathrm{E}_{3}\right)$, dan D) Radikula $\left(\mathrm{E}_{4}\right)$

Eksplan hipokotil dan radikula belum mampu dalam membentuk tunas. Hal tersebut dimungkinkan karena antara lain: pertama, zat pengatur tumbuh yang diberikan belum cukup optimal bagi eksplan untuk beregenerasi. Kedua, eksplan epikotil dan kotiledon lebih bersifat meristematik dibandingkan eksplan hipokotil dan radikula sehingga lebih mudah dalam proses pembelahan sel dan pembentukan tunas (Wulandari, 2002). Ketiga, eksplan hipokotil dan radikula kekurangan cadangan makanan, sehingga eksplan hanya mengandalkan penyerapan nutrisi hara dari media tumbuh saja tanpa adanya pembentukan tunas (Wulandari, 2002). Terlebih lagi, tidak adanya daun pada eksplan hipokotil dan radikula untuk proses fotosintesis meskipun pada bagian tersebut sudah terbentuk kalus dan mengandung klorofil. Proses fotosintesis lebih banyak dilakukan melalui daun dalam mendukung metabolisme suatu tanaman dibanding organ tanaman lainnya.

Jumlah tunas yang dihasilkan oleh eksplan epikotil lebih banyak dibandingkan pada eksplan kotiledon. Hal ini dimungkinkan pada eksplan epikotil telah terdapat daun yang mampu membantu secara optimal dalam proses fotosintesis untuk menghasilkan energi. Energi tersebut sebagai sumber tenaga untuk keperluan metabolisme eksplan. Selain itu, eksplan epikotil telah memiliki bentuk awal meristem yang nantinya mengalami proliferasi dan menjadi tunas ketika distimulasi oleh zat pengatur tumbuh (George \& Sherrington, 1984). Eksplan kotiledon menghasilkan jumlah tunas yang sedikit dapat dimungkinkan hal tersebut dimungkinkan karena posisi eksplan kotiledon yang vertikal saat kultur, sehingga inisiasi kalus dan pembentukan tunas hanya terpusat pada permukaan bawah eksplan dan terendam oleh media dasar. Menurut Pierik (1997) posisi eksplan horisontal waktu kultur dapat mendukung pembentukan tunas pada beberapa tanaman.

Bila dilihat dari pertumbuhan jumlah tunas, hasil ini serupa dengan penelitian Sudharson, Anbazhagan, Balachandran, dan Arumugam, (2014) pada Hybanthus enneaspermus dan Bhosale, Dubhashi, dan 
Rathod, (2011) pada berbagai varietas tanaman pisang, menyebutkan dimana semakin meningkat konsentrasi BAP jumlah tunas dan panjang tunasnya menurun. Hal tersebut dimungkinkan bahwa konsentrasi sitokinin yang tinggi atau BAP yang melebihi kadar optimum dapat menyebabkan jumlah tunas menurun dan terhambatnya perkembangan tajuk dan tunas (Tiwari, Tiwari, \& Singh, 2001). Penyebab lainnya adanya perbedaan jumlah tunas pada tiap eksplan, mungkin bisa dikarenakan ukuran eksplan, semakin kecil ukuran eksplan maka waktu insiasi tunas pun akan butuh waktu yang lama (Harahap et al., 2014). Hasil analisis keragaman menyebutkan bahwa hanya materi eksplan yang memiliki pengaruh yang nyata terhadap pembentukan jumlah tunas (Tabel 1), sehingga perlu adanya analisis lanjut mengenai materi eksplan apa yang paling berpengaruh dalam hal pembentukan tunas (Tabel 2). Sedangkan, pada analisis keragaman pertumbuhan panjang tunas menyebutkan bahwa pertumbuhan panjang tunas hanya dipegaruhi secara nyata oleh kombinasi materi eksplan dengan konsentrasi hormon BAP (Tabel 3). Analisis lanjut mengenai kombinasi materi eksplan dengan konsentrasi hormon BAP apa yang paling berpengaruh dalam hal pertumbuhan panjang tunas (Tabel 4).

Tabel 1. Analisis keragaman penambahan BAP dan bagian eksplan terhadap jumlah tunas gaharu (G. versteegii) 6 minggu setelah dikulturkan

\begin{tabular}{|c|c|c|c|c|c|c|}
\hline Sumber variasi & $\begin{array}{c}\text { Derajat } \\
\text { bebas }\end{array}$ & $\begin{array}{l}\text { Jumlah } \\
\text { kuadrat }\end{array}$ & $\begin{array}{c}\text { Kuadrat } \\
\text { tengah }\end{array}$ & F Hitung & & F Tabel \\
\hline \multirow[t]{2}{*}{ Media } & 3 & 10,998 & 3,67 & $3,04^{\mathrm{ns}}$ & $1 \%$ & 4,870 \\
\hline & & & & & $5 \%$ & 3,107 \\
\hline \multirow[t]{2}{*}{ Eksplan } & 3 & 360,808 & 120,27 & $99,68 * *$ & $1 \%$ & 4,027 \\
\hline & & & & & $5 \%$ & 2,715 \\
\hline \multirow{2}{*}{ Media x Eksplan } & 6 & 7,887 & 1,315 & $1,09^{\mathrm{ns}}$ & $1 \%$ & 3,027 \\
\hline & & & & & $5 \%$ & 2,210 \\
\hline Eror & 83 & 100,142 & 1,207 & & & \\
\hline Total & 95 & 479,656 & & & & \\
\hline
\end{tabular}

Keterangan: $\mathrm{ns}=$ Tidak berpengaruh nyata

$*$ = Berpengaruh nyata

$* *=$ Berpengaruh sangat nyata

Tabel 2. Hasil uji beda nyata DMRT pengaruh materi eksplan terhadap jumlah tunas pada taraf uji 5\%

\begin{tabular}{cc}
\hline Materi Eksplan & Rata-rata \\
\hline Epikotil & $4,357_{\mathrm{a}}$ \\
Kotiledon & $0,167_{\mathrm{b}}$ \\
Hipokotil & $0_{\mathrm{b}}$ \\
Radikula & $0_{\mathrm{b}}$ \\
\hline
\end{tabular}

Keterangan: Huruf yang berbeda menunjukkan perbedaan yang signifikan

Tabel 2 menunjukan hasil uji beda nyata materi eksplan terhadap pembentukan tunas pada eksplan. Tabel 2 memperlihatkan bahwa materi eksplan epikotil $\left(E_{1}\right)$ adalah eksplan yang paling tinggi dalam hal pembentukan tunas yaitu sebanyak 4,36 tunas. Hal tersebut menunjukkan bahwa pemilihan materi eksplan yang tepat akan lebih efektif dan mudah digunakan dalam kultur jaringan untuk pembentukan tunas.

Tabel 4 memperlihatkan pertumbuhan rerata panjang tunas tertinggi dihasilkan oleh perlakuan eksplan epikotil dengan konsentrasi BAP $0,7 \mathrm{mg} / \mathrm{l}\left(\mathrm{M}_{1} \mathrm{E}_{1}\right)$ yaitu $0,41 \mathrm{~cm}$ dalam waktu 6 minggu. Harahap et al. (2014) juga 
menyebutkan bahwa panjang tunas secara signifikan dipengaruhi oleh interaksi kombinasi BAP dengan tipe eksplan. Tiap eksplan memiliki pertumbuhan panjang tunas yang berbeda dimungkinkan karena serapan hara dan kemampuan regenerasi tiap eksplan yang berbeda. Eksplan pada penelitian berasal dari biji sehingga pertumbuhan dan perkembangannya pun tidak seragam, lain halnya eksplan yang berasal dari materi vegetatif. Pertumbuhan tunas pada eksplan kotiledon yang lambat, kemungkinan dikarenakan tunasnya yang terendam dalam media dasar.

Peningkatan konsentrasi BAP juga membuat pertumbuhan panjang tunas menurun. Hal tersebut dimungkinkan karena periode inkubasi eksplan yang terlalu lama dalam konsentrasi BAP, sehingga membuat pertumbuhan panjang tunas menjadi terhambat. Pendugaan tersebut sesuai dengan pernyataan Moncaleán, Rodríguez, dan Fernández, (2001) menyatakan bahwa pemberian konsentrasi BAP yang tinggi dapat menyebabkan pertumbuhan panjang tanaman menjadi terhambat.

\section{B. Tahap multiplikasi}

Multiplikasi merupakan cara meningkatkan perbanyakan pucuk atau tunas pada plantlet. Sebelum mengkulturkan eksplan hasil tahap induksi ke botol kultur baru, kalus pada eksplan dikurangi terlebih dahulu. Hal tersebut bertujuan agar tunas eksplan dapat mengalami pertumbuhan dan perkembangan nantinya, bukan pada kalus.

Tabel 3. Analisis keragaman penambahan BAP dan bagian eksplan terhadap panjang tunas gaharu (G. versteegii) 6 minggu setelah dikulturkan

\begin{tabular}{lcccccc}
\hline \multicolumn{1}{c}{ Sumber variasi } & $\begin{array}{c}\text { Derajat } \\
\text { bebas }\end{array}$ & $\begin{array}{c}\text { Jumlah } \\
\text { kuadrat }\end{array}$ & $\begin{array}{c}\text { Kuadrat } \\
\text { tengah }\end{array}$ & F Hitung & F Tabel \\
\hline Media & 3 & 0,024 & $1,17^{\text {ns }}$ & $1,17^{\text {ns }}$ & $1 \%$ & 4,87 \\
& & & & & $5 \%$ & 3,11 \\
Eksplan & 3 & 1,785 & 0,595 & $83,38^{* *}$ & $1 \%$ & 4,03 \\
& & & & & $5 \%$ & 2,72 \\
Media x Eksplan & 6 & 0,118 & 0,019 & $2,75^{\text {ns }}$ & $1 \%$ & 3,03 \\
Eror & 83 & 0,592 & 0,007 & & $5 \%$ & 2,21 \\
Total & 95 & 2,647 & & & \\
\hline
\end{tabular}

Keterangan: $\mathrm{ns}=$ Tidak berpengaruh nyata

$$
\begin{aligned}
* & =\text { Berpengaruh nyata } \\
* * & =\text { Berpengaruh sangat nyata }
\end{aligned}
$$

Tabel 4. Hasil uji beda nyata DMRT kombinasi perlakuan konsentrasi hormon bap dengan materi eksplan terhadap panjang tunas pada taraf uji $5 \%$

\begin{tabular}{cccc}
\hline Perlakuan & Rata-rata & Perlakuan & Rata-rata \\
\hline $\mathrm{M}_{1} \mathrm{E}_{1}$ & $0,409_{\mathrm{a}}$ & $\mathrm{M}_{1} \mathrm{E}_{3}$ & $\mathrm{O}_{\mathrm{c}}$ \\
$\mathrm{M}_{2} \mathrm{E}_{1}$ & $0,258_{\mathrm{b}}$ & $\mathrm{M}_{2} \mathrm{E}_{4}$ & $0_{\mathrm{c}}$ \\
$\mathrm{M}_{4} \mathrm{E}_{2}$ & $0,252_{\mathrm{b}}$ & $\mathrm{M}_{2} \mathrm{E}_{3}$ & $0_{\mathrm{c}}$ \\
$\mathrm{M}_{2} \mathrm{E}_{2}$ & $0,031_{\mathrm{c}}$ & $\mathrm{M}_{2} \mathrm{E}_{4}$ & $0_{\mathrm{c}}$ \\
$\mathrm{M}_{4} \mathrm{E}_{2}$ & $0,011_{\mathrm{c}}$ & $\mathrm{M}_{4} \mathrm{E}_{3}$ & $0_{\mathrm{c}}$ \\
$\mathrm{M}_{1} \mathrm{E}_{2}$ & $0_{\mathrm{c}}$ & $\mathrm{M}_{4} \mathrm{E}_{4}$ & $0_{\mathrm{c}}$ \\
\hline
\end{tabular}

Keterangan: Huruf yang berbeda menunjukkan perbedaan yang signifikan. Konsentrasi BAP 0,7 mg/l $\left(\mathrm{M}_{1}\right)$, Konsentrasi BAP 1,0 mg/l ( $\left.\mathrm{M}_{2}\right)$, Konsentrasi BAP 1,5 mg/l $\left(\mathrm{M}_{3}\right)$, Konsentrasi BAP 2,0 mg/l (M4), Epikotil ( $\left.E_{1}\right)$, Kotiledon ( $\left.E_{2}\right)$, Hipkotil $\left(E_{3}\right)$, dan Radikula $\left(E_{4}\right)$ 


\section{Jumlah tunas dan panjang tunas}

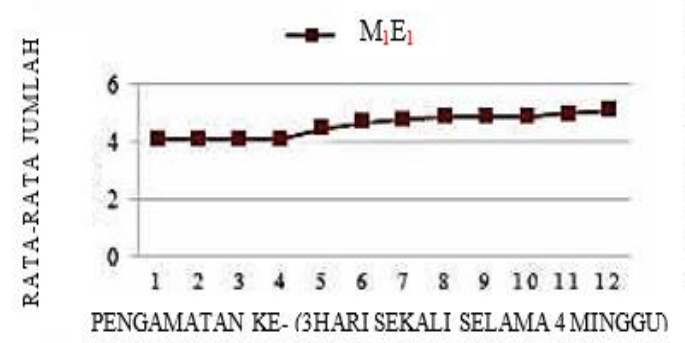

A

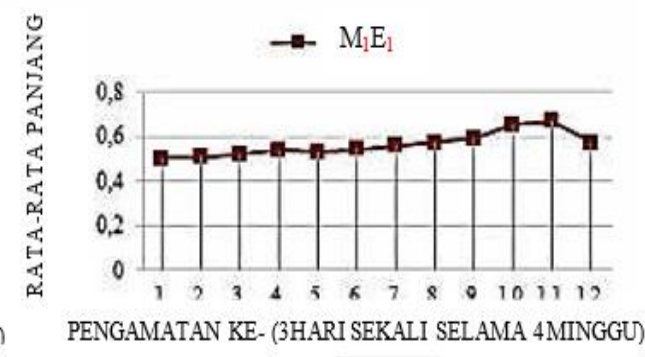

B

Keterangan: Konsentrasi BAP 0,7 mg/l ( $\left.\mathrm{M}_{1}\right)$ dan Epikotil $\left(\mathrm{E}_{1}\right)$

Gambar 5. Dinamika Pertumbuhan A) Rerata Jumlah Tunas dan B) Rerata Panjang Tunas pada Eksplan Terbaik dalam Media yang Terbaik Selama Pengamatan Subkultur

Peningkatan jumlah tunas pada eksplan terjadi sekitar 16 hari atau 2 minggu setelah kultur. Rerata Jumlah tunas mengalami peningkatan menjadi 5,1 tunas dalam waktu 4 minggu. Rerata Jumlah tunas ini meningkat 0,3 tunas dari tahap induksi tunas sebelumnya. Pertumbuhan panjang tunas mengalami peningkatan sekitar 3-5 hari atau 1 minggu setelah kultur dilakukan. Rerata panjang tunas meningkat menjadi $0,58 \mathrm{~cm}$ dalam waktu 4 minggu. Rerata panjang tunas meningkat 0,28 $\mathrm{cm}$ dari tahap induksi tunas.

Perbedaan perkembangan tiap eksplan dalam hal panjang dan jumlah tunas pada penelitian ini dimungkinkan karena faktor respon eksplan terhadap media baru subkultur dalam menyerap hara. Sebagian eksplan kemungkinan kandungan hara dalam tubuhnya menurun sehingga ketika disubkulturkan ke media baru, eksplan tersebut merespon dalam bentuk pertumbuhan tunas baru dan panjang tunas. Sebagian tunas eksplan lainnya yang tidak mengalami pertumbuhan tunas baru dan panjang tunas dimungkinkan karena pada tubuh eksplan masih memiliki kandungan hara yang cukup dari kultur sebelumnya. Kemungkinan lainnya yaitu karena kesesuaian zat pengatur yang diberikan saat tahap multiplikasi.

\section{Tahap perakaran}

Kondisi perakaran yang baik yaitu ditinjau dari segi jumlah akar dan panjang akar, karena dapat mempengaruhi keberhasilan hidup eksplan ketika ditumbuhkan diluar botol kultur saat proses aklimatisasi. Eksplan yang digunakan adalah tunas dari eksplan hasil pengamatan akhir tahap multiplikasi. Tunas kemudian diseleksi dengan kriteria minimal panjang tunas $0,5 \mathrm{~cm}$. Tahap perakaran ini diberikan perlakuan berupa kombinasi hormon NAA $0,01 \mathrm{mg} / \mathrm{l}$ dengan konsentrasi hormon IBA (1,0 mg/l, 2,0 mg/l, 3,0 $\mathrm{mg} / \mathrm{l}$, dan 4,0 mg/l). Tahap ini menunjukkan keberhasilannya menggunakan kombinasi IBA dan NAA dalam memacu tumbuhnya akar pada eksplan. Aplikasi kombinasi IBA dan NAA bisa menginduksi pembentukan akar saat kultur jaringan dan auksin eksogen ini bisa berinteraksi dengan auksin internal yang mana tidak bisa bersintesis akibat jaringan/organ yang terbatas dan kecil sehingga kemampuan auksin internal dalam membentuk perakaran terbatas. Terlebih lagi kemampuan IBA yang superior dibanding auksin lainnya karena sifatnya yang stabil dan tidak mudah dalam memecah enzim yang penting digunakan dalam metabolisme atau mendukung pembentukan akar (Salih, Shmarey, \& Dabagh, 2016). 


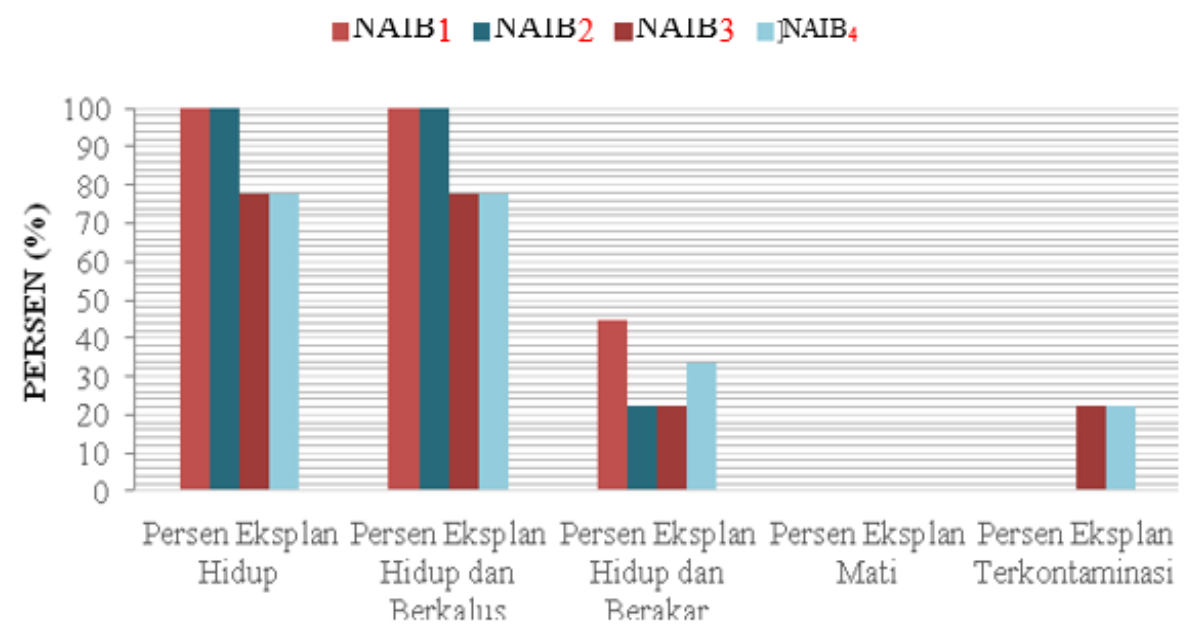

Keterangan: Hormon NAA 0,01 mg/l (NA), Konsentrasi IBA 1,0 mg/l (IB1), Konsentrasi IBA 2,0 mg/l (IB2), Konsentrasi IBA 3,0 mg/l (IB3), dan Konsentrasi IBA 4,0 mg/l (IB4)

Gambar 6. Persentase Eksplan Hidup, Berkalus, Berakar, Mati, dan Terkontaminasi Hingga Pengamatan Ke12 (Selama 4 Minggu)

\section{Jumlah akar dan panjang akar}

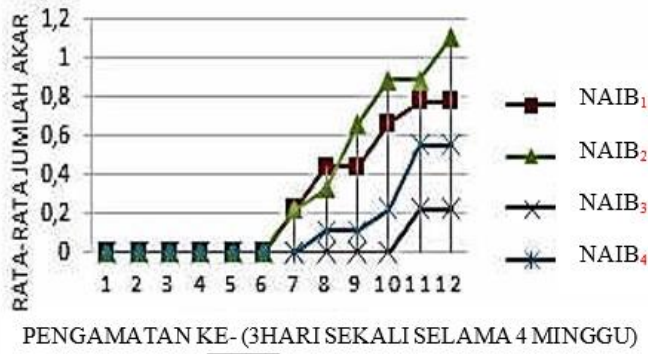

A

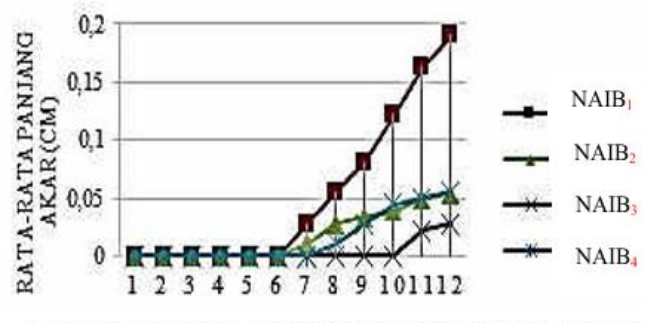

PENGAMATAN KE-(3HARI SEKALI SELAMA 4MINGGU)

Keterangan: Hormon NAA 0,01 mg/l (NA), Konsentrasi IBA 1,0 mg/l (IB $\left.{ }_{1}\right)$, Konsentrasi IBA 2,0 mg/l (IB 2 ), Konsentrasi IBA 3,0 mg/l (IB 3 ), dan Konsentrasi IBA 4,0 mg/l ( $\left.\mathrm{IB}_{4}\right)$

Gambar 7. Dinamika Pertumbuhan A) Rerata Jumlah Akar danB) Panjang Akar Tiap Perlakuan hingga Pengamatan Ke-12 (Selama 4minggu)

Rerata jumlah akar tertinggi terdapat pada kombinasi perlakuan hormon NAA $0,01 \mathrm{mg} / \mathrm{l}$ dengan konsentrasi hormon IBA 2,0 mg/l (NAIB 2 ) yaitu 1,11 akar (Gambar 7A). Gambar 7A juga memaparkan bahwa peningkatan konsentrasi IBA lebih dari 2,0 mg/l dapat menurunkan jumlah akar yang terbentuk. Hasil jumlah akar yang menurun seiring meningkatnya penambahan konsentrasi auksin sesuai dengan penelitian Rajora, Sharma, dan Sharma, (2013) pada tanaman Catharanthus roseus yaitu meningkatnya konsentrasi IBA lebih dari $6 \mathrm{mg} / \mathrm{l}$ menyebabkan perkembangan jumlah akar pada eksplan menurun. Hal itu dimungkinkan pemberian dosis auksin yang tinggi akan menyebabkan pertumbuhan eksplan menjadi terhambat, baik itu tunas maupun perakaran (Rajora et al., 2013; Rostiana \& Seswita, 2007). Beberapa eksplan ada yang tidak mengalami pembentukan perakaran. Hal tersebut kemungkinan kurangnya konsentrasi NAA yang diberikan, karena menurut Fuchs, (1986) hormon NAA juga memiliki peran dalam meningkatkan jumlah akar. kemungkinan lainnya adalah pembentukan akar pada eksplan dihambat oleh etilen yang dipicu akibat kinerja hormon auksin 
di dalam sel tumbuhan, terutama jika auksin eksogen ditambahkan akan meningkatkan akumulasi etilen tersebut (George \& Sherrington, 1984).

Tabel 5. Analisis keragaman penambahan kombinasi IBA dan NAA terhadap jumlah akar eksplan gaharu (G. verstegii) 4 minggu setelah dikulturkan

\begin{tabular}{ccccccr}
\hline $\begin{array}{c}\text { Sumber } \\
\text { Variasi }\end{array}$ & Derajat Bebas & $\begin{array}{c}\text { Jumlah } \\
\text { kuardrat }\end{array}$ & $\begin{array}{c}\text { Kuadrat } \\
\text { Tengah }\end{array}$ & F Hitung & \multicolumn{2}{c}{ F Tabel } \\
\hline Perlakuan & 3 & 2,698 & 0,899 & $0,42^{\text {ns }}$ & $1 \%$ & 4,57 \\
Eror & 28 & 59,302 & 2,118 & & $5 \%$ & 2,95 \\
Total & 31 & 62 & & & & \\
\hline
\end{tabular}

Keterangan: $\mathrm{ns}=$ Tidak berpengaruh nyata

$*$ = Berpengaruh nyata

$* *=$ Berpengaruh sangat nyata

Tabel 6. Analisis keragaman penambahan kombinasi IBA dan NAA terhadap panjang akar eksplan gaharu (G. verstegii) 4 minggu setelah dikulturkan

\begin{tabular}{ccccccr}
\hline $\begin{array}{c}\text { Sumber } \\
\text { Variasi }\end{array}$ & Derajat Bebas & $\begin{array}{c}\text { Jumlah } \\
\text { kuardrat }\end{array}$ & $\begin{array}{c}\text { Kuadrat } \\
\text { Tengah }\end{array}$ & F Hitung & \multicolumn{2}{c}{ F Tabel } \\
\hline Perlakuan & 3 & 0,125 & 0,042 & $0,42^{\text {ns }}$ & $1 \%$ & 4,57 \\
Eror & 28 & 112 & 0,02 & & $5 \%$ & 2,95 \\
Total & 31 & 1,245 & & & & \\
\hline
\end{tabular}

Keterangan: $\mathrm{ns}=$ Tidak berpengaruh nyata

$*=$ Berpengaruh nyata

$* *=$ Berpengaruh sangat nyata

Gambar 7B menunjukkan pemberian kombinasi hormon NAA dengan konsentrasi IBA lebih dari $1,0 \mathrm{mg} / \mathrm{l}$ menyebabkan panjang akar menurun. Hasil ini serupa halnya dengan penelitian Harahap et al. (2014) dimana peningkatan pemberian IBA pada kombinasinya dengan NAA memberikan dampak penurunan panjang akar. Hal tersebut sesuai dengan pernyataan Salisbury et al. (1995) yaitu pemberian auksin salah satu perannya yaitu dapat memacu pembentukan dan pemanjangan akar pada konsentrasi rendah sedangkan konsentrasi tinggi bisa menghambatnya. Hal ini didukung juga oleh ungkapan Salguero (2000) dimana pemberian auksin eksogen yang tinggi dapat pula menghambat proses elongasi akar. Hal tersebut dikarenakan juga oleh adanya akumulasi etilen dalam tubuh eksplan yang terdapat pada ujung akar.

Perlakuan kombinasi antara hormon NAA dengan konsentrasi hormon IBA yang diberikan tidak memberikan pengaruh yang nyata baik terhadap pertumbuhan panjang akar (Tabel 5) maupun jumlah akar yang muncul (Tabel 6).
Perbedaan pembentukan jumlah akar dan pertumbuhan panjang akar dimungkinkan antara lain: pertama eksplan masih memiliki kandungan sitokinin yang cukup tinggi dari tahap sebelumnya, karena dosis sitokinin tinggi dapat menghambat pertumbuhan akar (George \& Sherrington, 1984) Kedua, karena serapan masing-masing eksplan yang berbeda-beda terhadap auksin yang diberikan dan waktu yang dibutuhkan eksplan dalam memacu pertumbuhan dan perpanjangan akar karena NAA dan IBA memiliki sifat translokasi auksin yang agak lambat dan aktivitasnya juga lambat (Harahap et al., 2014). Ketiga, eksplan masih memiliki kandungan auksin endogen yang tinggi didalam tubuhnya sehingga pemberian auksin eksogen bisa menyebabkan perpanjangan akarterhambat.

\section{KESIMPULAN}

Penelitian yang dilakukan terbatas pada penentuan penggunaan metode propagasi $G$. versteegii yang sesuai dengan hasil yaitu bahwa materi eksplan epikotil dengan 
konsentrasi BAP $0,7 \mathrm{mg} / \mathrm{l}\left(\mathrm{M}_{1} \mathrm{E}_{1}\right)$ memiliki jumlah tunas dan panjang tunas tertinggi untuk tahap induksi tunas. Epikotil merupakan materi eksplan yang paling mudah, cepat dan paling tinggi kemampuan bertunasnya untuk multiplikasi subkultur tunas gaharu (G.versteegii). Pemberian hormon BAP pada tiap materi eksplan hanya berpengaruh terhadap pertumbuhan panjang tunas eksplan saat tahap induksi tunas. Penambahan kombinasi hormon NAA dan IBA terhadap eksplan tunas gaharu (G. versteegii) tidak berpengaruh pada pembentukan jumlah akar dan pertumbuhan panjang akar saat tahap perakaran.

\section{UCAPAN TERIMA KASIH}

Penulis mengucapkan banyak terima kasih kepada Balai Besar Penelitian dan Pengembangan Bioteknologi dan Pemuliaan Tanaman Hutan (BBPPBPTH) Purwobinangun, Yogyakarta khususnya Laboratorium Kultur Jaringan atas segala usaha dan dukungan yang diberikan baik finansial, moral, tenaga, administrasi, serta sarana dan prasarana laboratorium kultur jaringan pada penelitian ini sehingga dapat terlaksana dengan baik dan lancar. Penelitian ini merupakan bagian dari tesis penulis yang menjadi persyaratan dalam mencapai jenjang strata 2 .

\section{DAFTAR PUSTAKA}

Ashraf, M. F., Aziz, M. A., Kemat, N., \& Ismail, I. (2014). Effect of cytokinin types, concentrations and their interactions on in vitro shoot regeneration of Chlorophytum borivilianum sant. \& fernandez. Electronic Journal of Biotechnology, 17(6), 275-279. https://doi.org/10.1016/j.ejbt.2014.08.004

Bhosale, U. P., Dubhashi, S. V, \& Rathod, H. P. (2011). In vitro shoot multiplication in different species of Banana. Asian Journal of Plant Science and Research, 1(3), 23-27.

CITE. (2004). Consideration of Proposals for Amendment of Appendices I and II. Sixteenth meeting of the Conference of the Parties.

Fuchs, H. W. M. (1986). Root regeneration of rose plants as influenced by applied auxins. Acta Horticulture, 189, 13-19.
George, E. F., \& Sherrington, P. D. (1984). Plant propagation by tissue culture. London: Eastern Press.

Harahap, F., Poerwanto, R., Suharsono, Suriani, C., \& Rahayu, S. (2014). In Vitro Growth and Rooting of Mangosteen (Garcinia mangostana L.) on Medium with Different Concentrations of Plant Growth Regulator. HAYATI Journal of Biosciences, 21(4), 151158. https://doi.org/10.4308/hjb.21.4.151

Hartmann, H. T., Kester, D. E., Davies, F. T., \& Geneve, R. L. (1990). Hartmann and Kester ' $S$ Plant Propagation: Principles and practices (5th ed.). New York: Prentice Hall.

Hendaryono, D. P. S., \& Wijayani, A. (2012). Teknik kultur jaringan: pengenalan dan petunjuk perbanyakan tanaman secara vegetatif modern. Yogyakarta: Penerbit kanisius.

Herawan, T., \& Hendrati, R. L. (1996). Petunjuk Teknis Kegiatan Kultur Jaringan. Informasi Teknis (Vol. 2). Yogyakarta.

Jensen, A. (2003). Domestication of Aquilaria spp and rural poverty sosio economic and genetic aspects of the planting boom in the "wood of Gods." In English (pp. 233-239). NAFRI Workshop Proceedings Shifting Cultivation and Poverty Eradication in the Uplands of the Lao PDR.

Moncaleán, P., Rodríguez, A., \& Fernández, B. (2001). In vitro response of Actinidia deliciosa explants to different BA incubation periods. Plant Cell, Tissue and Organ Culture, 67(3), 257-266.

https://doi.org/https://doi.org/10.1023/A:1012 732429147

Mucharromah. (2009). Pengembangan gaharu di Sumatera. In S. A. Siran \& M. Turjaman (Eds.), Pengembangan Teknologi produksi gaharu berbasis pemberdayaan masyarakat sekitar hutan (pp. 35-52). Bogor: Pusat Penelitian dan Pengembangan Hutan dan Konservasi Alam.

Mulyaningsih, T., \& Yamada, I. (2008). Notes on some species of agarwood in Nusa Tenggara, Celebes and West papua. In Natural resource management and socio-economic transformation under the decentralization in Indonesia: Toward Sulawesi area studies (pp. 365-372). Kyoto: CSEAS. Kyoto University.

Muswita. (2011). Pengaruh Konsentrasi Bawang Merah (Alium Cepa 1.) Terhadap Pertumbuhan Setek Gaharu (Aquilaria Malaccencis Oken). Jurnal Penelitian Universitas Jambi Seri Sains, 13(1), 15-20. 
Pierik, R. L. . (1997). In Vitro Culture of Higher Plants. New York: Springer Science \& Business Media.

Power, J. B., \& Ochat, S. J. (1992). Plant regeneration from cultured protoplast of higher plant. In M. W. Fowler, G. S. Warren, \& M. Moo-Young (Eds.), Plant biotechnology: comprehensive biotechnology (Second Sup, pp. 99-128). New York: Pergamon Press.

Rajora, R. K., Sharma, N. K., \& Sharma, V. (2013). Effect of plant growth regulators on micropropagation of Catharanthus roseus. International Journal of Advanced Biotechnology and Research, 4(1), 123-130.

Rostiana, O., \& Seswita, D. (2007). Pengaruh Indole Butyric Acid dan Naphtaleine Acetic Acid terhadap induksi tunas Piretrum [Chrysanthemum cinerariifolium ( Trevir .) Vis .] klon prau 6 secara in vitro. Buletin Littro, XVIII(1), 39-48.

Sabdin, Z. M. H., Muid, S., \& Sani, H. (2011). Micropropagation of Aquilaria malaccensis Lank and Aquilaria microcarpa Baill, 2(October), 3-5.

Salguero, J. (2000). Exogenous effect on root growth and ethylene production in maize primary roots.

Salih, M. I., Shmarey, I. A. Al, \& Dabagh, F. M. K. Al. (2016). Indole-3-Butyric Acid and Naphthalene Acetic Acid Impacts on in Vitro Rooting of Mariana and Nemaguard Rootstocks. IOSR Journal of Agriculture and Veterinary Science, 9(7), 50-53. https://doi.org/10.9790/2380-0907025053
Salisbury, F. B., Ross, C. W., \& Lukman, D. R. (1995). Fisiologi tumbuhan jilid 3 : perkembangan tumbuhan dan fisiologi lingkungan. System (4 ed). Bandung: ITB Bandung.

Sidiyasa, K., \& Mira, K. N. (2009). Beberapa sifat dasar dari benih pohon penghasil gaharu (Aquilaria microcarpa) di KHDTK Kamboja, Kalimantan Timur. Mitra Hutan Tanaman, 4(2), 67-79.

Sudharson, S., Anbazhagan, M., Balachandran, B., \& Arumugam, K. (2014). Effect of BAP on In vitro propagation of Hybanthus enneaspermus (L.) Muell, an important medicinal plant. International Journal of Current Microbiology and Applied Sciences, 3(8), 397-402.

Sumarna, Y. (2012). Budidaya jenis pohon penghasil gaharu. Bogor: Pusat Litbang Produktivitas Hutan, badan Penelitian dan Pengembangan Kehutanan.

Tiwari, V., Tiwari, K. N., \& Singh, B. D. (2001). Comparative studies of cytokinins on in vitro propagation of Bacopa monniera. Plant Cell, Tissue and Organ Culture, 66(1), 9-16.

Wulandari, R. S. (2002). Pengaruh pemberian auksin dan sitokinin terhadap pertumbuhan eksplan kultur jaringan pada Gmelina arborea Linn. Universitas Gadjah Mada Yogyakarta.

Zulkarnain. (2014). Kultur Jaringan Tanaman, Solusi Perbanyakan Tanaman Budidaya (2nd ed.). Jakarta: Bumi Aksara. 
Jurnal Pemuliaan Tanaman Hutan

Vol. 11 No. 1, Juni 2017, p. 1 - 13 